\title{
Features of small scale enterpreneur and access to credit in Nigeria: a microanalysis
}

\author{
F.A. Ajagbe \\ Lecturer Department of Management Science and Accounting Ladoke Akintola University of \\ Technology, PMB 4000 Ogbomoso Nigeria,
}

\begin{abstract}
This study investigates determinants of access of small-scale enterprises to credit in Nigeria. Three hundred and fifty respondents were selected using stratified sampling techniques. Descriptive statistics such as percentages, frequency distribution and logit regression were employed in analyzing the data. The results showed sex, age, marital status, family size, capital assets, interest rate, and level of education and other dwelling characteristics of small-scale enterprises influence access to use of credit from credit institutions.
\end{abstract}

Key works: Small-scale enterprises, Access to Credit, Credit Markets, Nigeria.

\section{INTRODUCTION}

Different people choose to use the available sources of credit to suit their personal and economic features. These futures have been found to determine the decision to apply for credit at all, and whether to apply from either formal or informal lenders. However, their effects on the lenders decision to ration applicants differ between the two market segments (Zeller, 1994).

Household and enterprises characteristic are usually related to borrowing behaviour and purposes, with enterprises using specific sources of finance for particular purposes (Aryeetey, 1996). Hence with money lenders being the most expensive source of credit; demand for credit from the source comes mainly from those without any other alternative. For example house holds may borrow from money lenders during food scarcity to maintain their consumption until the next harvest.

Mazzarol et al., (1999) cited by Adegbite (2006) reported that female entrepreneurs were generally less likely to be founders of new manufacturing business than male. In other words, males had significantly higher entrepreneurial intention than females.

Kristiansen et al., 2003 revealed a significant correlation between age of the entrepreneur and business success. However, the aged (over 25 yrs) were more successful than the younger ones.

Reynolds (1999) and Headd (2003) cited by Adegbite (2006) established a positive relationship between marital status and business performance. In their study of small scale entrepreneurs in the United States of America (USA), married men and women performed better in managing a business than single, divorce or widowed individuals. Tolentino (1998); Gibb (1998); and Onstenk (2003) found that educated individuals are more likely to be involved in entrepreneurial activity. This also pre-supposes that they are generally able to appreciate the need to make use of banks, cooperatives and money lenders.

\section{MATERIALS AND METHODS}

This study was carried out in four geo-political zones of Oyo State, Nigeria. A well structured questionnaire was designed to obtain relevant information from 350 respondents chosen through stratified sampling techniques.

The primary data were analyzed using such as descriptive statistics analysis percentage, and frequency distributions. The method is employed to analyze the respondents visa-a-viz, the gender, educational status, family size, age, and marital status, capital assets interest rate and income of the respondents. In other to examine the association between the socio-economics characteristics and access to and demand for credit from credit markets, Logit regression was employed because of the quantitative nature of most of the variables.

Logit model is presented thus:

$K_{i t}=f\left(A G_{i t}, E d_{i t}, S X_{i t}, M T_{i t}, H S_{i t}, D S_{i t}, A C_{i t}, A S_{i t}, D W_{i t}\right.$, $\left.R R_{i t}, R G_{i t} \ldots \ldots.\right) \quad(1)$

Where $\mathrm{K}_{\mathrm{it}}$ is a dummy variable taking a value of 1 if the individual took credit and 0 otherwise, $A G_{i t}$, $\mathrm{Ed}_{\mathrm{it}}$, 
$\mathrm{SX}_{\text {it }}$, and $\mathrm{MT}_{\text {it }}$ are the age, education gender, and marital status of the individual $\mathrm{i}$ and the $\mathrm{t}$, and $\mathrm{HS}_{\mathrm{it}}$, $D S_{i t}, A C_{i t}$, are the household size, distance to district centre and main activity of the individual, respectively. $A S_{i t}, D W_{i t}, R R_{i t}$, and $R G_{i t}$ are value of household assets, dummies for location in the rural areas and set of dummies representing the different regions (Ibadan/lbarapa, Ogbomoso, Oyo and OkeOgun). We assume that for an individual $\mathrm{K}^{*}$ it represents the critical decision point of taking credit or not, and thus summarize this information as:

Individual $\mathrm{i}$ takes credit if $\mathrm{K}_{\mathrm{it}}>\mathrm{K}^{*}{ }_{\text {it }}$ and $\mathrm{K}^{*}=1$ individual $\mathrm{i}$ does not take credit if $\mathrm{K}_{\text {it }}<\mathrm{K}_{\text {it }}^{*}$ and therefore $K_{i t}^{*}=0$

Table 1: Frequency and percentage Distribution of Respondents by their socio-economic characteristics $\mathbf{N}=\mathbf{3 5 0}$

\begin{tabular}{|c|c|c|c|}
\hline Socio-Economic characteristics & Frequency & $\begin{array}{l}\text { Percentage } \\
\%\end{array}$ & Cumulative \\
\hline \multicolumn{4}{|l|}{ Rural And Urban Location } \\
\hline Ibadan/lbarapa & 200 & 57.1 & 57.1 \\
\hline Ogbomoso & 70 & 20.0 & 77.1 \\
\hline Oyo & 50 & 14.3 & 91.4 \\
\hline Oke-ogun & 30 & 8.6 & 100.0 \\
\hline \multicolumn{4}{|l|}{ Gender } \\
\hline Male & 227 & 64.9 & 64.9 \\
\hline Female & 123 & 35.1 & 100.0 \\
\hline \multicolumn{4}{|l|}{ Age } \\
\hline Less than 30 & 1 & 0.3 & 0.3 \\
\hline $31-40$ & 99 & 28.3 & 28.6 \\
\hline $41-50$ & 142 & 40.6 & 69.2 \\
\hline $51-60$ & 61 & 17.4 & 86.6 \\
\hline 61 above & 47 & 13.4 & 100.0 \\
\hline \multicolumn{4}{|l|}{ Household Assets } \\
\hline Less than $-\mathrm{N} 100,000.00$ & 45 & 12.9 & 12.9 \\
\hline $\mathrm{N} 100,000.00-\mathrm{N} 300,000.00$ & 127 & 36.3 & 49.1 \\
\hline $\mathrm{N} 300,000.00-\mathrm{N} 500,000.00$ & 108 & 30.9 & 80.0 \\
\hline $\mathrm{N} 500,000.00-\mathrm{N} 700,000.00$ & 35 & 10.0 & 90.0 \\
\hline $\mathrm{N} 700,000.00-\mathrm{N} 1000,000.00$ & 18 & 5.1 & 95.1 \\
\hline N1Million above & 17 & 4.9 & 100.0 \\
\hline \multicolumn{4}{|l|}{ Educational Status } \\
\hline Primary & 70 & 20.0 & 20.0 \\
\hline Post primary & 197 & 56.3 & 76.3 \\
\hline Vocational/Technical & 61 & 17.4 & 93.7 \\
\hline Tertiary & 22 & 6.3 & 100.0 \\
\hline \multicolumn{4}{|l|}{ Source of Revenue } \\
\hline Personal savings & 228 & 64.6 & 64.6 \\
\hline Relatives & 26 & 7.4 & 72.0 \\
\hline Friends & 14 & 4.0 & 76.0 \\
\hline Money/enders & 30 & 8.6 & 84.6 \\
\hline Bank loan & 4 & 1.1 & 85.7 \\
\hline Multiple Responses & 50 & 14.3 & 100.0 \\
\hline \multicolumn{4}{|l|}{ Access to Credit } \\
\hline Formal & 46 & 13.1 & 13.1 \\
\hline Informal & 223 & 63.8 & 76.9 \\
\hline Both & 6 & 1.7 & 78.6 \\
\hline
\end{tabular}

The probit models also assume error term and General model can be presented thus:

$Y_{\text {it }}=\alpha_{0}+\alpha_{1} A G_{i t}+a_{2} E D_{i t}+\alpha_{3} S X_{i t}+\alpha_{4} F S_{i t}+\alpha_{5} A S_{i t}+$ $\alpha_{6} I C_{i t}+\alpha_{7} D C_{i t}+\alpha_{8} P C_{i t}+\alpha_{9} C M_{i t} \alpha_{10} B S i t+\alpha_{11} D S i t$

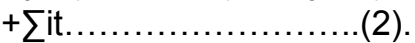

\section{RESULTS AND DISCUSSION}

A summary of the distribution of these variables among the beneficiaries is presented in Table 1 . About $64.9 \%$ of the respondents were male while $35.1 \%$ were female. The need to encourage women to seek credit facilities is still very expendient in thye study areas. 
Am. J. Soc. Mgmt. Sci., 2012, 3(1): 39-44

\begin{tabular}{|c|c|c|c|}
\hline No ideal & 75 & 21.4 & 100.0 \\
\hline \multicolumn{4}{|l|}{ Demand for Credit } \\
\hline Yes & 317 & 90.6 & 90.6 \\
\hline No & 33 & 9.4 & 100.0 \\
\hline \multicolumn{4}{|l|}{ Interest rate } \\
\hline $20 \%$ & 210 & 60.0 & 60.0 \\
\hline $30 \%$ & 97 & 27.7 & 87.7 \\
\hline $40 \%$ & 42 & 12.0 & 99.7 \\
\hline $50 \%$ & 1 & 0.3 & 100.3 \\
\hline \multicolumn{4}{|l|}{ Marital status } \\
\hline Single & 99 & 28.3 & 28.3 \\
\hline Married & 251 & 71.7 & 100.0 \\
\hline \multicolumn{4}{|c|}{ Main Activity of Business } \\
\hline Agriculture & 29 & 8.3 & 8.3 \\
\hline Industry & 10 & 2.9 & 11.1 \\
\hline Business & 240 & 68.6 & 79.7 \\
\hline Transport & 50 & 14.3 & 94.0 \\
\hline Administration & 21 & 6.0 & 100.0 \\
\hline \multicolumn{4}{|l|}{ Apply for } \\
\hline Yes & 300 & 85.7 & 85.7 \\
\hline No & 50 & 14.3 & 100.0 \\
\hline \multicolumn{4}{|c|}{ Most pressing Problem } \\
\hline Poor market & 16 & 4.6 & 4.6 \\
\hline Poor management & 40 & 11.4 & 16.0 \\
\hline Lack of capital & 242 & 69.1 & 85.1 \\
\hline Lack of education & 49 & 14.0 & 99.1 \\
\hline Others & 3 & 0.9 & 100.0 \\
\hline \multicolumn{4}{|l|}{ Collateral } \\
\hline Yes & 342 & 97.7 & 97.7 \\
\hline No & 8 & 2.3 & 100.0 \\
\hline
\end{tabular}

Source: Field Survey, 2010

The table also shows that $0.3 \%$ of the respondents were less than age of 30 years. $28.3 \%$ were within 31-40 age group, while $40.6 \%$ where between 51 60years of age, just about $13.4 \%$ were more than 60 years old. The mean age of 45.4 years is an indication that the population sampled was predominantly middle aged. These ages- groups are known to be energetic and strong and therefore expected to be save and/or borrow for investment than the old. While the old depend mostly on their past savings and accumulated wealth to smooth their consumption.

In respect of their marital status, about $71.7 \%$ were married while $28.3 \%$ were single. The mean stood at 0.28 meaning that, the married are more likely to be relatively stable, making financial institutions to view them as more reliable and makes them more likely to demand for credit compared to the married.

The result of the educational status of the respondents is in Table 1 . Twenty percent had primary education, $56.3 \%$ had post primary education, $17.4 \%$ had vocational/Technical education while the remaining $6.3 \%$ had attended either polytechnic or Universities. The mean of 2.10 is obtained. The distribution clearly reveals that, all the respondents (100\%) had acquired one level of education or the other. This presupposes that they were generally able to appreciate the need to make use of both formal and informal credit institutions as well as to evaluate information for business improvement and productivity.

Table 1 also justifies the level of income of individual as respondents that would determine the demand for credit. When income is low, the household has limited resources to save and less demand for credit than at higher level of income. With means of 2.73 this implies that individual with high income will be able to demand for more loans in large amount to improve their business.

Interest rate is another factor that can affect demand for credit. All things being equal (ceteris paribus), the higher that interest rate charged the lower the 
demand for credit. The interest rate charged is between $20 \%$ and $50 \%$ with the means of $25.31 \%$. This suggests that borrowers who do not have access to formal credit institution because of their high rate of interest charged would decide to demand

Table 4.1.2: Descriptive statistics variables in the Model

\begin{tabular}{|c|c|c|c|c|}
\hline Variables & Minimum & Maximum & Mean & Std. deviation \\
\hline Rural and Urban location & 1 & 4 & 1.74 & 0.997 \\
\hline Gender & 0 & 1 & 0.65 & 0.478 \\
\hline Age & 0 & 4 & 2.49 & 0.942 \\
\hline Family size & 1 & 5 & 2.63 & 1.054 \\
\hline Ownership of the Business & 0 & 1 & 0.80 & 0.401 \\
\hline Membership Composition & 1 & 5 & 1.39 & 0.709 \\
\hline Amount applied for & 1 & 5 & 2.27 & 0.947 \\
\hline Household Assets & 1 & 6 & 2.73 & 1.245 \\
\hline Educational Status & 1 & 4 & 2.10 & 0.786 \\
\hline Initial Capital & 1 & 6 & 2.45 & 0.877 \\
\hline Source of Revenue & 1 & 6 & 2.25 & 1.934 \\
\hline Amount disbursed & 1 & 6 & 2.36 & 1.077 \\
\hline Past credit used & 1 & 5 & 2.69 & 0.912 \\
\hline Access to Credit & 1 & 4 & 2.12 & 0.634 \\
\hline Category of sources of credit & 1 & 4 & 2.03 & 1.136 \\
\hline Choice of Credit & 1 & 5 & 1.70 & 0.815 \\
\hline Bank Account & 0 & 1 & 0.94 & 0.232 \\
\hline Type of Account & 1 & 5 & 2.16 & 1.417 \\
\hline Demand for Credit & 0 & 1 & 0.91 & 0.293 \\
\hline Type of Loan & 0 & 5 & 1.52 & 1.009 \\
\hline Application Period & 1 & 5 & 2.39 & 1.074 \\
\hline Contribution by Credit market & 1 & 4 & 2.23 & 0.909 \\
\hline Collateral security & 0 & 1 & 0.98 & 0.150 \\
\hline Impact of Informal Credit on devt. & 1 & 4 & 2.36 & 0.858 \\
\hline Terms \& condition of formal credit & 1 & 4 & 2.80 & 0.786 \\
\hline Informal credit problem & 0 & 1 & 0.15 & 0.359 \\
\hline Informal credit terms \& Condition & 1 & 4 & 1.38 & 0.691 \\
\hline Implication of formal credit & 1 & 5 & 1.71 & 0.879 \\
\hline Terms and conditions of F.G. easy & 0 & 1 & 0.97 & 0.182 \\
\hline Preferred policy & 1 & 4 & 2.09 & 0.582 \\
\hline Recommendation & 1 & 4 & 1.97 & 0.808 \\
\hline Interest rate & 20 & 50 & 25.31 & 7.121 \\
\hline Effect of interest charged & 1 & 4 & 2.14 & 0.713 \\
\hline Nature of business before Loan & 1 & 5 & 3.96 & 0.661 \\
\hline Most pressing problems & 1 & 5 & 2.95 & 0.686 \\
\hline Marital status & 0 & 1 & 0.28 & 0.451 \\
\hline Main activity of business & 1 & 5 & 3.07 & 0.860 \\
\hline Apply for & 0 & 1 & 0.14 & 0.350 \\
\hline Credit purpose & 0 & 1 & 0.09 & 0.280 \\
\hline Received credit before & 0 & 1 & 0.86 & 0.347 \\
\hline Application successful & 0 & 1 & 0.72 & 0.451 \\
\hline
\end{tabular}

Source: Field Survey, 2010 
Am. J. Soc. Mgmt. Sci., 2012, 3(1): 39-44

Table 3: Logit Regression of whether Individual has access to formal and informal credit institutions or not have accessDependable variable: Access to credit

\begin{tabular}{|c|c|c|c|c|c|}
\hline Explanatory variable & Personal Savings & Relatives/friends & Money Lender & Bank Loan & Multiple Sources \\
\hline $\operatorname{Ln}($ age) & $0.260(1.57)$ & $-0.293(-1.41)$ & $-0.902(-1.70)$ & $0.028(0.11)$ & $0.718(1.54)$ \\
\hline Ln (yeard of education) & $-0.398(-2.04)^{\star \star}$ & $0.565(2.32)^{\star \star}$ & $-0.987(-0.21)$ & $-0.844(-.28)$ & $-0.474(-0.71)$ \\
\hline Dummy: gender & $-0.026(-0.08)$ & $0.305(0.73)$ & $-0.634(-0.71)$ & $0.575(1.24)$ & $0.387(0.33)$ \\
\hline Dummy: ownership & $0.944(2.74)^{\star \star}$ & $-0.318(-3.08)^{\star \star *}$ & $-2.348(-2.18)^{\star *}$ & $-0.125(-0.17)$ & $1.763(1.54)$ \\
\hline Post and current credit use & $-0.778(-4.33)^{\star * \star}$ & $-0.307(-1.30)$ & $-0.806(-1.41)$ & $0.828(-2.20)^{\star *}$ & $6.504(4.37)^{\star \star \star}$ \\
\hline Income & $0.022(0.18)$ & $-0.482(-2.48)^{\star *}$ & $0.526(1.36)$ & $0.393(1.88)^{\star *}$ & $-0.290(-0.64)$ \\
\hline Collateral & $-0.270(-0.24)$ & -- & $1.117(0.30)$ & $1.620(1.63)$ & $0.313(0.05)$ \\
\hline Application period & $0.230(1.11)$ & $-0.010(-0.03)$ & $-1.576(1.77)^{*}$ & $-0.813(-3.06)^{\star \star \star}$ & $-0.846(-0.72)$ \\
\hline Type of Account & $1.119(3.54)^{\star \star \star}$ & $-0.010(-0.02)$ & $1.376(1.10)$ & $-0.004(-1.69)^{*}$ & $-6.44(-3.23)^{* \star *}$ \\
\hline Type of Loan & $-0.528(-1.29)$ & $1.200(1.77)^{\star}$ & $0.754(0.75)$ & $0.319(0.46)$ & $-2.139(-0.95)$ \\
\hline Interest rate & $-0.172(-6.94)^{\star \star \star}$ & $-0.012(-0.36)$ & $0.302(3.27)^{\star \star \star}$ & $0.068(1.50)$ & $-0.128(-1.09)$ \\
\hline Ibadan & $0.133(0.26)$ & $-0.152(0.26)$ & $-0.212(-0.15)$ & $-17.273(-20.49)^{\star * \star}$ & $-0.414(-0.29)$ \\
\hline Ogbomoso & $0.265(0.48)$ & $-0.068(-0.10)$ & $-\quad-$ & $-17.319(-18.54)^{\star * *}$ & $0.506(0.26)$ \\
\hline Oyo & $-0.994(-0.17)$ & $-2.17(-1.89)^{\star \star}$ & $1.472(1.13)$ & -16.923 & $2.477(0.73)$ \\
\hline Constant & $5.963(3.10)^{\star \star \star}$ & $-0.116(-0.06)$ & $-6.793(-0.92)$ & $15.969(5.80)^{\star \star \star}$ & $-18.120(1.85)^{\star \star}$ \\
\hline Number of Obs. & 350 & 342 & 280 & 350 & 350 \\
\hline LR Chi 2 (14) & 1132.62 & 40.17 & 138.58 & 71.09 & 249.46 \\
\hline Prob. > chi 2 & 0.0000 & 0.0001 & 0.00000 & 0.0000 & 0.0000 \\
\hline Pseudo R2 & 0.2914 & 0.1649 & 0.7268 & 0.3251 & 0.8689 \\
\hline
\end{tabular}

Source: Field Survey, 2010

\footnotetext{
* Significant at $10 \%$

** Significant at $5 \%$

*** Significant at $1 \%$
} 
for credits from the informal credit markets whose terms and conditions were more reliable and easy.

In terms of household asset, the mean stood at 2.73 this shows that the higher the valuable assets, certificate of occupancy or tittle deeds on a particular property the higher the propensity of such an individual to seek credit facility from formal and informal credit markets. Location, this shows that rural respondents will depend mostly on informal credit while the urban areas will have to depend on formal credit because the further away of individual from district centre the lower the like-hood of security credit from commercial banks, even from the various sources (Mpuga, 2008).

Activities of the respondents, some activities required large amounts of capital while other requires less. So, the demand for credit will be affected by the activity of primary engagement of the respondents.

The result of the probit regression to test for the significant relationship between whether individuals have access to credit or not and socio-economic characteristics of the respondents is shown in Table $2-3$. Table $2-3$ have coefficient of 9 variables that were statistically significant at $1 \%, 5 \%$ and $10 \%$ probability levels. This implies that all the variables namely age, education, ownership of the business, past and current credit use, type of account, income, interest rate, location and application period should be taken into consideration by formal and informal financial institutions before approval of loan application to ensure that approval is given only to people (whether rural or urban) that will use the loan judiciously, improve their well being and pay back at when due.

CONCLUSION: The study showed that demand for credit is strongly influenced by gender, age, education, marital status, family size, location, value of assets owned and other dwelling characteristics. Also there exist significant relationship between socio-economic characteristics of the respondents and their access to use of credit from formal and informal credit institutions.

It is against this background that these recommendations were made that, women should be encouraged to seek credit facilities from credit institutions. Besides, it is necessary to provide a policy environment that affords the necessary incentives for enterprise to grow.

\section{REFERENCES}

Adegbite, S.A. (2006): Effect of Technical Entrepreneurial characteristics on the performance of small-scale manufacturing industries in Oyo State. An unpublished M.Sc. thesis in the Department of Technology Management, Obafemi Awolowo University, Ile-Ife.

Aryeetey, E. (1996): "Rural finance in Africa: institutional Developments and access for the poor". The World Bank Africa Conference on Development Economics, $25-26$ April, Washington, D.C.

Kristiansen, S., Furuholf, B., and Walid, F. (2003): "Internet café Entrepreneurs: Pioneers in information Dissemination in Idonesia. The Internal.

Mpuga, M. (2008): Constraints in Access to and Demand for rural credit. Evidence from Uganda. A paper for presentation during the African Economic Conference (AEC) 12 - 14 November 2008, Tunis, Tunisia.

Onstenk, I., (2003): "Entrepreneurship and Vocational Education. Dutch Experience". A publication. (Netherlands: centre for innovation of vocational education and Training).

Tolentino, A, (1998): Training and Development of Entrepreneurs and Managers of small Enterprises pointers and lessons learned.(General: International labour organization).

Zeller, M., (1994): "Determinants of credit rationing". A study of informal lenders and formal credit groups in Madagascar". World Development, Vol.22, No.12: $1895-1907$ 